\title{
A IDENTIFICAÇÃO DE ELEMENTOS INTANGÍVEIS EM PAISAGENS NÃO TÃO NOTÁVEIS: O CASO DO CALÇADÃO DA RUA CARDOSO VIEIRA EM CAMPINA GRANDE/PB
}

\author{
IDENTIFICATION OF INTANGIBLE ELEMENTS IN LANDSCAPES NOT SO REMARKABLE: \\ THE CASE OF THE CARDOSO VIEIRA PEDESTRIAN STREET IN CAMPINA GRANDE/PB
}

\author{
Hugo Stefano Monteiro Dantas \\ Kainara Lira dos Anjos
}

\begin{abstract}
RESUMO
O presente artigo busca entender como os elementos intangíveis de paisagens não tão notáveis, aquelas que não possuem atributos excepcionais, podem ser elencados e utilizados como ferramentas para a conservação não apenas de tais paisagens, mas também da memória urbana local. Para isso, o Calçadão da rua Cardoso Vieira, localizado em Campina Grande/PB, foi escolhido como objeto empírico do estudo. A partir de autores como Ziayee (2018), Gehl Institute (2018) e Strauss e Corbin (2008), foi realizado um recorte dos elementos a serem elencados no local e algumas etapas metodológicas foram levantas para a operacionalização de tais teorias: pesquisa documental, visitas in loco, aplicação de entrevistas semiestruturadas e aplicação de um método etnográfico observacional. A partir dos resultados obtidos, concluiu-se que nas paisagens não tão notáveis os elementos intangíveis possuem valores que, embora não sejam universais, são de grande importância para a escala de seus usuários, aumentando assim, o nível de pertencimento e da conexão dos mesmos com o local. Dessa forma, torna-se claro que os elementos intangíveis de paisagens não tão notáveis devem receber a atenção adequada para a devida conservação da paisagem, igualmente como da memória e da história do local.
\end{abstract}

Palavras-chave: Paisagem, paisagens não tão notáveis, elementos intangíveis.

\section{Abstract}

This article seeks to understand how the intangible elements of not-so-remarkable landscapes, those that don't have exceptional attributes, can be listed and used as tools for the conservation not only of such landscapes, but also of the local urban memory. For this, the "Calçadão" on Cardoso Vieira Street, located in Campina Grande/PB, was chosen as the empirical object of the study. From authors such as Ziayee (2018), Gehl Institute (2018) and Strauss and Corbin (2008), a cut was made of the elements to be listed on the site and some methodological steps were selected for the operationalization of such theories: documentary research, on-site visits, application of semi-structured interviews and application of an observational ethnographic method. Based on the data collected, it is concluded that in the not-so-remarkable landscapes, intangible elements have values that are not universal, but are of great importance for the scale of their users, thus increasing the level of belonging and connection of users with the location. Thus, it becomes clear that the intangible elements of not-so-remarkable landscapes must be preserved for the proper conservation of the landscape, as well as the memory and history of the place.

Key-words: Landscape; not-so-remarkable landscapes; intangible elements. 


\section{INTRODUÇÃO}

A paisagem como termo e noção têm sua gênese por volta de 1415 na Holanda'. Entretanto, foi apenas na época do Renascimento, a partir de descobertas como a perspectiva, que o conceito pode se instalar dentro da sociedade. Com o tempo, a paisagem deixa de ser apenas um ornamento da pintura "adquirindo uma consistência de uma realidade para além do quadro" (CAUQUELIN, 2007, p. 37). A paisagem extrapola os quadros e pinturas, passa a ser projetada pelos arquitetos paisagistas e cerca de quinhentos anos depois, em conjunto com todos os seus elementos, passa a incorporar em suas análises a abordagem patrimonial. Isso ocorre quando a UNESCO, a partir dos anos 1990, acrescenta nas questões patrimoniais o conceito de paisagem cultural, combinando de forma inextricável os aspectos materiais e imateriais da paisagem (CASTRIOTA, 2009).

A paisagem nas questões de salvaguarda patrimonial não é de fato uma novidade no fim do século XX. Ainda no início desse século, personagens como Gustavo Giovannoni já defendiam a sua proteção, ou da ambiência do local, nas suas palavras, como um dos prismas da defesa das cidades italianas da época ${ }^{2}$. O que de fato é inovador na conceituação da UNESCO é a inclusão da salvaguarda dos aspectos intangíveis da paisagem. Tais aspectos podem ser entendidos como:

as práticas, representações, expressões, conhecimentos e técnicas - junto com os instrumentos, objetos, artefatos e lugares culturais que lhes são associados - que as comunidades e grupos e, em alguns casos, os indivíduos reconhecem como parte integrante de seu patrimônio cultural. (UNESCO, 2006, p.4)

Entretanto, é visto que mesmo entre as diversas ampliações que os conceitos de paisagem e patrimônio passaram nas últimas décadas, o tom de excepcionalidade no tocante aos bens imóveis que devem ser preservados prevalece. Esse fato pode ser visto na definição de paisagens culturais que a UNESCO atribuiu no docu-

1 Para melhor entendimento da invenção da paisagem, ver Cauquelin (2007).

2 Para um estudo mais aprofundado da questão, ver Cabral (2013). mento intitulado "Diretrizes operacionais para a implementação da Convenção do Patrimônio Mundial" em 1999:

Paisagens culturais (...) são ilustrativas da evolução da sociedade e dos assentamentos humanos ao longo do tempo, sob a influência das determinantes físicas e/ou oportunidades apresentadas por seu ambiental natural e das sucessivas forças sociais, econômicas e culturais, tanto internas, quanto externas. Elas deveriam ser selecionadas com base tanto em seu extraordinário valor universal e sua representatividade em termos de região geocultural claramente definida, quanto a sua capacidade de ilustrar os elementos culturais essenciais e distintos daquelas regiões. (Grifo nosso) (UNESCO, 1999, p. 9)

Essa definição permanece basicamente inalterada na edição mais recente do documento datada de 2017. Nela é adicionada a definição do que seria o extraordinário valor universal:

Extraordinário valor universal significa uma significância natural e/ou cultural que é tão excepcional que transcende as fronteiras nacionais e é de importância comum para as gerações presentes e futuras de toda a humanidade. Como tal, a proteção permanente deste patrimônio é da mais alta importância para a comunidade internacional como um todo. (UNESCO, 2017, p. 19)

Dessa forma, a salvaguarda de todos os elementos da paisagem ainda acontece de maneira restrita. Em contrapartida ao extraordinário valor universal, é assinada em Florença nos anos 2000, a Convenção Europeia de Paisagem. Nesse decreto, a paisagem como um todo se torna protagonista ao se abranger o olhar patrimonial da Paisagem Cultural para todos os seus tipos. Assim, todo o território passa a ser considerado como cultural, por ser a expressão da cultura local.

Até agora as administrações públicas estatais, regionais e locais, só redigiram leis para protegerem aquelas paisagens consideradas de valor especial, como os parques 
naturais ou alguns tipos de monumentos históricos. Com esta forma de abordarmos a proteção da paisagem, corremos o risco de esquecermos que todo o território é paisagem, mesmo aqueles lugares mais normais, como a zona em que vivemos e que, possivelmente, não tem nenhum valor histórico ou natural de exceção. (DI MAIO; BERENGO, 2011, p. 12)

Esse decreto, mesmo que represente um ato político e econômico (VERAS, 2014), significou um grande avanço ao fomentar as ideias da preservação da paisagem. A Convenção pode ser assim entendida como um marco conceitual definitivo para o futuro das paisagens, e não só da Europa. Entretanto, como foi supracitado, o extraordinário valor universal continua em vigência na operacionalização da salvaguarda da Paisagem Cultural pelos órgãos patrimoniais. Esse entendimento faz com que as paisagens ordinárias, ou aqui tratadas como paisagens não tão notáveis, fiquem de fora dessa dinâmica patrimonial.

Essa exclusão acaba refletindo também a nível nacional, uma vez que as candidaturas brasileiras também necessitam responder ao extraordinário valor universal da UNESCO. Dessa forma, o número de paisagens culturais chanceladas pelo IPHAN atualmente, permanece reduzido a duas: as paisagens cariocas entre a montanha e o mar na cidade do Rio de Janeiro, RJ, e o Conjunto Moderno da Pampulha na cidade de Belo Horizonte, MG. ${ }^{3}$

As paisagens não tão notáveis muitas vezes são representações de lugares de memória onde elementos intangíveis "dão sentido ao lugar e o lugar é fundador de tais práticas. As vivências e as relações sociais manifestam-se na paisagem desses lugares. Essas relações se dão, também, por meio de uma sobreposição de ideias, crenças, valores e sentimentos vinculados à dimensão imaterial." (NÓR, 2013, p. 123). Assim, as paisagens não tão notáveis, mesmo sem possuir elementos intangíveis e tangíveis que ultrapassem as fronteiras nacionais, necessitam ter esses elementos identificados e conservados para as gerações futuras. Ainda segundo Nór (2013), a conservação dos elementos intangíveis e

3 A lista completa de bens classificados como Paisagens Culturais pode ser encontrada em https://whc.unesco.org/en/culturallandscape/. tangíveis configura-se como um novo desafio nos dias de hoje para as questões patrimoniais.

Nessa dinâmica patrimonial, Carsalade (2015) aponta como as metodologias de planejamento urbano utilizadas no último século estiveram pouco atentas aos aspectos intangíveis da paisagem.

No planejamento urbano a cultura aparece como um ponto de análise setorial, geralmente pensada de forma pontual e nos seus capítulos finais. A ausência de uma investigação das culturas locais acaba por gerar erros nas estratégias de implementação e gestão, além de deformar o verdadeiro significado e a expressão simbólicas dos locais onde o planejamento se aplica. (CARSALADE, 2015, p. 384)

Desse modo, pode-se perceber como a identificação dos elementos intangíveis da paisagem se constitui como parte indispensável para a total salvaguarda do bem patrimonial. É preciso assim que metodologias para a operacionalização da salvaguarda desses elementos sejam difundidas no ideário de preservação nacional para que os aspectos culturais da paisagem também possam ser identificados e preservados.

\section{Identificação dos Elementos Intangíveis da PAISAGEM}

Concordando com o que foi explanado até aqui, Ziyaee (2014) define paisagem cultural como um complexo sistema de transformação do meio ambiente pela ação humana. Essa seria a arte de moldar o espaço por meio da noção de cultura. Essa relação entre a força humana e o meio ambiente se daria por meio da sobreposição dos elementos tangíveis e intangíveis. No tocante à identificação dos elementos intangíveis da paisagem, sendo esse o objeto de estudo deste trabalho, a revisão bibliográfica feita por Ziayee (2018) e resumida no Quadro 01, revela quais os principais elementos devem ser identificados nas paisagens culturais de acordo com uma gama de autores na literatura internacional: 
Quadro 1: Levantamento das características das paisagens culturais através da literatura internacional. Fonte: adaptado de Ziayee (2018).

\begin{tabular}{|c|c|c|}
\hline \multicolumn{3}{|c|}{ Levantamento das características das paisagens culturais através da literatura internacional } \\
\hline Autores & Elementos & Sub-elementos \\
\hline \multirow{2}{*}{ Brown (2001) } & Elementos tangiveis & $\begin{array}{l}\text { Vias, tipo de pavimentação, terrenos de importância cultural, } \\
\text { principais preocupações das áreas comerciais/industriais. }\end{array}$ \\
\hline & Elementos Intangiveis & Fronteiras políticas de censo, limites proprietários, usos da terra. \\
\hline \multirow{2}{*}{ O’Donell (2008) } & Valores tangiveis & $\begin{array}{l}\text { Sistemas naturais, usos da terra, padrōes, organização espacial, } \\
\text { relaçōes visuais, topografia, vegetaçōo, sistemas de circulaçāo, } \\
\text { recursos hídricos, estruturas e edifícios paisagísticos naturais } \\
\text { e construídos, edifícios náo habitúveis, características espaciais, } \\
\text { forma e escala de estruturas habitáveis, vocabulário de mobiliário local. }\end{array}$ \\
\hline & Valores intangíveis & $\begin{array}{l}\text { Festivais, música tradicional, dança, performance, peregrinação, } \\
\text { adoração, comemoração de eventos passados, práticas tradicionais, } \\
\text { local de encontro de plantas nativas, lugar comunitário de memória } \\
\text { e uso atual. }\end{array}$ \\
\hline \multirow{3}{*}{ Stephenson (2008) } & Formas & $\begin{array}{l}\text { Formas naturais (topografia, vegetação, etc). } \\
\text { Intervenções humanas (estruturas, jardins, etc). }\end{array}$ \\
\hline & Relações & $\begin{array}{l}\text { Memórias, símbolos, ideologias, espiritualidade, identidade do lugar, } \\
\text { estética/beleza, estórias e mitos, o significado do nome do lugar, } \\
\text { sensaçóo de pertencimento. }\end{array}$ \\
\hline & Práticas & $\begin{array}{l}\text { Sistemas humanos, processos ecológicos, atividades humanas, } \\
\text { eventos históricos, processo histórico, atividades tradicionais, } \\
\text { processos nocionais. }\end{array}$ \\
\hline \multirow{2}{*}{ Vogeler (2010) } & Significados culturais & Ideias e crenças. \\
\hline & Formas físicas & $\begin{array}{l}\text { Topografia, vegetação, estrutura } \\
\text { (tempo/espaço, intenção visuais), padrão de assentamento. }\end{array}$ \\
\hline \multirow{4}{*}{ Sonkorley (2017) } & \multirow{2}{*}{ Patrimônio cultural vivo } & $\begin{array}{l}\text { Tangiveis: itens de uso cultural/religioso, itens de uso doméstico } \\
\text { (comida, vestimenta, etc), produto de uso industrial }\end{array}$ \\
\hline & & $\begin{array}{l}\text { Intangíveis: senso de identidade, padróo de uso do espaço, } \\
\text { expressóo (fala, maneiras, costumes, sistema de crenços, } \\
\text { atividades comerciais/culturais/sociais. } \\
\end{array}$ \\
\hline & \multirow{2}{*}{$\begin{array}{l}\text { Patrimônio } \\
\text { cultural construído }\end{array}$} & $\begin{array}{l}\text { Tangiveis: edifícios/grupo de edificios, jardins } \\
\text { e parques públicos, monumentos e estruturas, } \\
\text { terrenos arqueológicos. }\end{array}$ \\
\hline & & $\begin{array}{l}\text { Intangíveis: padrão de uso do solo, } \\
\text { padráo de uso de edificios, expressóo } \\
\text { (arquitetura/paisagem urbana), senso de identifdade. }\end{array}$ \\
\hline
\end{tabular}


A partir da revisão bibliográfica feita por Ziyaee (2018)4 é possível perceber que os autores tendem a considerar os elementos da paisagem cultural a partir das duas categorias já discutidas anteriormente: o físico (tangível) e o não físico (intangível). A partir do Quadro 01, é possível ainda perceber como os elementos intangíveis elencados em 2001 possuíam um cunho muito mais técnico (fronteiras, limites, usos da terra) e como a partir de 2008 a questão cultural passou a ter maior predominância nesses elementos.

A partir do estudo de Ziyaee (2018), foram escolhidos os elementos intangíveis e tangíveis expostos e sintetizados no Quadro 02 abaixo. Esse novo recorte foi feito a partir da experiência empírica dos autores com o objeto em estudo. Para tanto, foram consideradas as configurações específicas do Calçadão, tais, como: seu recorte espacial; sua pequena extensão de área e seu recorte histórico; sua inserção em um Centro Histórico cuja conformação atual é resultado de processos de urbanização tardios (décadas de 1930-1950), se comparado a outras cidades de origem coloniais; entre outras.

Cabe aqui salientar que, conforme aponta Queiroz (2008), na cidade de Campina Grande as reformas urbanas que moldaram o que chamamos de Centro Histórico tiveram o intuito de tornar a cidade civilizada, urbana, industrial e moderna. Assim, as expressões tangíveis e intangíveis que não fossem consideradas como modernas foram retirados desse centro. Então, muitos dos elementos citados por Ziyaee (2018), como festas e músicas tradicionais, não são comuns no centro da cidade, não podendo ser elencados e analisados na atualidade.

Por mais interessante que seja a identificação dos elementos tangíveis do objeto empírico, neste trabalho serão tratados apenas os elementos intangíveis. Entendendo ainda que, em um possível levantamento de elementos voltado para o reconhecimento de uma paisagem cultural, a identificações dos dois tipos de elementos possuem a mesma importância. ${ }^{5}$

4 Ziyaee (2018) não conceitua os valores elencados em sua revisão bibliográfica, esses serão conceituados ao decorrer do texto do artigo, durante a identificação dos mesmos.

5 Este artigo se configura como um aprofundamento da temática discutida no Trabalho de Conclusão de Curso do autor (2018), onde foram identificados os elementos tangíveis e intangíveis do objeto em estudo.
Para a identificação dos elementos intangíveis da paisagem do Calçadão, alguns procedimentos metodológicos foram elencados. O primeiro deles foi constituído pela pesquisa documental em arquivos como o Arquivo Municipal da Prefeitura de Campina Grande, que está no processo de catalogação dos projetos urbanos da cidade, e os arquivos online do Jornal da Paraíba. Concluída a pesquisa documental, foi realizada pesquisa de campo a partir de visitas in loco no Calçadão, aplicação de entrevistas semiestruturadas e aplicação do Método Etnográfico Observacional para a observação da dimensão humana proposto pelo Gehl Institute (2016).

A entrevista semiestruturada nos ajudou a entender se o objeto de estudo apresenta relações sociais e afetivas integradas com o ambiente e a visualizar a percepção das pessoas que utilizam a área de estudo. As perguntas presentes na entrevista possuíam respostas abertas, o usual para entrevistas semiestruturadas, para que assim a fala dos entrevistados pudesse revelar diferentes aspectos acerca da memória coletiva do local.

Por sua vez, a observação da dimensão humana foi realizada a partir do Método Etnográfico e observacional desenvolvido pelo Gehl Institute (2016) e publicado na cartilha Public Life Diversity Toolkit. Nesse método, pesquisadores observam a apropriação no espaço público para entender as nuances de como as pessoas se movimentam e usam o espaço. Esse método etnográfico registra como as pessoas "votam com os pés" e descobre padrões de uso entre diferentes grupos demográficos.

Dessa maneira, a análise dos elementos intangíveis do Calçadão da Cardoso Vieira será explanada em dois momentos: o primeiro deles referente ao significado do nome do lugar, que irá englobar a pesquisa documental feita no arquivo online do Jornal da Paraíba, enquanto que o segundo momento irá analisar concomitante a memória coletiva, a sensação de pertencimento e o uso atual do local, a partir das visitas in loco e da aplicação do método etnográfico e observacional. Entende-se aqui que tais elementos intangíveis podem ser analisados a partir da mesma ferramenta. Por exemplo, enquanto um entrevistado relata suas memórias com o local, o mesmo pode explanar a sua relação afe- 
Quadro 02: Elementos levantados pelo autor (2018).

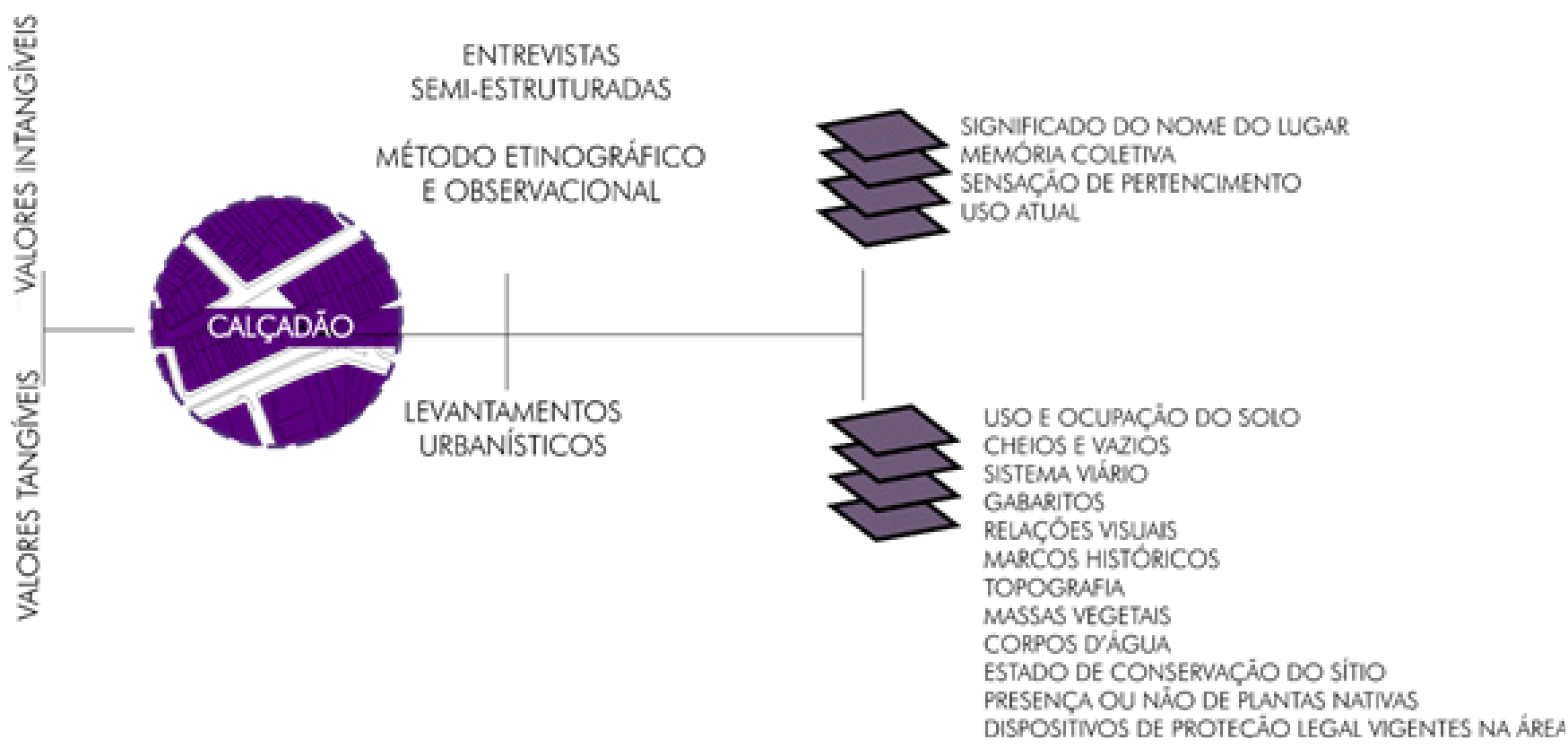

tiva e o seu place attachment (CHAWLA, 19992), ou seja, o seu vínculo, a sua ligação com o local.

\section{O Calçadão da Cardoso Vieira}

O Calçadão da rua Cardoso Vieira está inserido no centro urbano da cidade Campina Grande, onde as centralidades urbana e histórica partilham o mesmo espaço (ver fig. 01). Localizada no Nordeste brasileiro, Campina Grande é a segunda cidade mais populosa do estado da Paraíba, estando situada no planalto da Borborema, um importante centro regional por sua dinâmica socioeconômica. Possui uma população equivalente a pouco mais de 400 mil habitantes, exercendo influência sob os 60 municípios ao seu entorno.

O Calçadão, como foi supracitado, é localizado no centro histórico da cidade, o qual foi palco de diversas reformas urbanas higienistas que, até a década de 1940, procuraram desmontar ou inibir símbolos seculares e modernizar a vida social da cidade. Dessa maneira, o traçado urbano que tinha uma característica irregular é destruído para dar lugar a um desenho urbano retilíneo voltado a circulação automobilística, da mesma forma que o patrimônio eclético sede lugar para novas construções no estilo Art Déco.6 Essas reformas afetam diretamente as expressões culturais do centro da cidade, onde ficam privilegiados os aspectos sociais voltados para a elite urbana.

Na década de 1970 é proposto a execução do Plano de Desenvolvimento Local Integrado - PDLI, que, segundo Carvalho (2017), prio-

6 Para maior aprofundamento da temática, ver Queiroz (2008). 


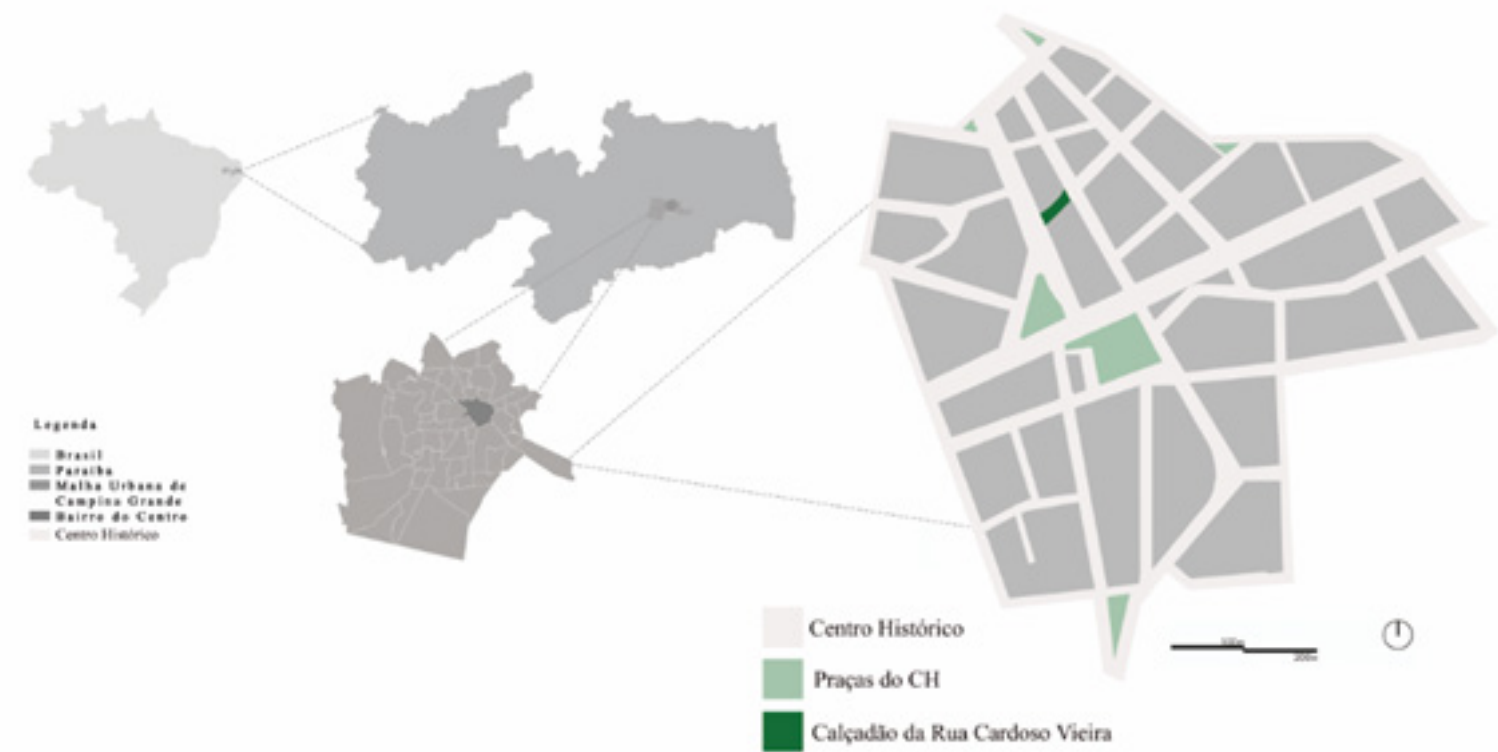

Calçadio da Rua Cardoso Vicira

Figura 01: Localização do Calçadão da Cardoso Vieira. Fonte: Produzido pelos autores, 2018

rizou dentre suas medidas de ação preparar o centro principal da cidade dotando-o de toda a infraestrutura pela imediata urbanização e requalificação de seus principais equipamentos e logradouros público. Assim, justificava-se porque era ali que se concentrava grande parte dos cinemas clubes, auditórios de rádios, igrejas e mesmo praças e passeios que serviram durante muito tempo para o desfile das elites campinenses. Propõe-se, dessa forma, a cidade como expressão cultural, de lazer e recreação.

Foi a partir desse contexto que a COMDECA - Companhia de Pródesenvolvimento de Campina Grande -, comissão composta por diversos arquitetos, engenheiros e desenhistas, chefiada pelo arquiteto campinense Renato Azevedo, ficou à frente dos projetos de intervenção urbanística no centro da cidade. Ainda em 1972, a COMDECA propõe a construção de um calçadão na área central de Campina Grande, quem vem a ser construído em 1975. Assim, Campina seria uma das primeiras cidades do país a adotar em seu planejamento urbano o calçadão como espaço público democrático. Segundo Dittrich et. al. (2000), o Calçadão de Curitiba foi o primeiro a ser executado em 1970, tendo algumas cidades feito o mesmo nos anos seguintes.

Desde a sua criação, o Calçadão passa por diversas reformas que, além de modificar fisicamente o traçado do seu desenho, ampliaram e diminuíram a sua extensão entre os anos de 1982-1993 (ver fig. 02). Entretanto, o trecho inicial do Calçadão permaneceu o mesmo até os dias de hoje. Essa decisão é justificada por sua importância cultural para o Centro da cidade: 
Ao reafirmar, ontem, a possibilidade de extinção dos calçadões situados nas ruas centrais de Campina Grande, o Secretário Edvan Pereira Leite, (...) garantiu que o mais tradicional deles, que fica na Cardoso Vieira não será demolido, por entender que para aquele setor acorrem as mais expressivas personalidades deste município, cuja finalidade relaciona-se ao debate sobre política e a vida da cidade, de modo geral. (...) (SECRETÁRIO diz que pode haver extinção de calçadões. DB, 06 nov. 1987, Caderno Cidades apud CARVALHO, 2017, p. 229).

\section{Os Elementos Intangíveis do Calçadão da Cardoso Vieira}

Como mencionado anteriormente, para a apreensão da paisagem cultural, é fundamental a identificação e análise dos ele- mentos intangíveis. No caso do Calçadão Cardoso Vieira, foram analisados os seguintes elementos: significado do nome do lugar; memória coletiva; atores; e uso atual.

\subsection{SignifiCADO DO NOME DO LUGAR}

De acordo com a pesquisa de Ziyaee (2018), o significado do nome do lugar é um dos elementos intangíveis que devem ser levados em consideração ao se tratar de paisagens culturais. Essa importância vem do fato de que o nome dado ao local pode revelar parte da sua história ou do significado do local para a sociedade.

Na cidade de Campina Grande, os nomes dados aos espaços públicos são escolhidos pela câmara de vereadores da cidade. Isso acarreta, majoritariamente, na escolha de nomes que representem a elite campinense e muitas vezes não possuem ligação alguma com

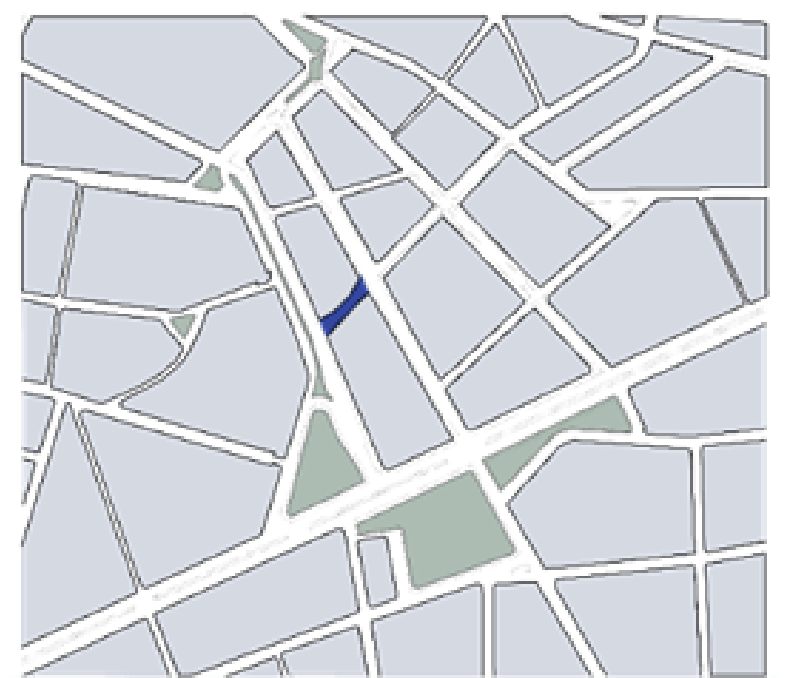

(1)

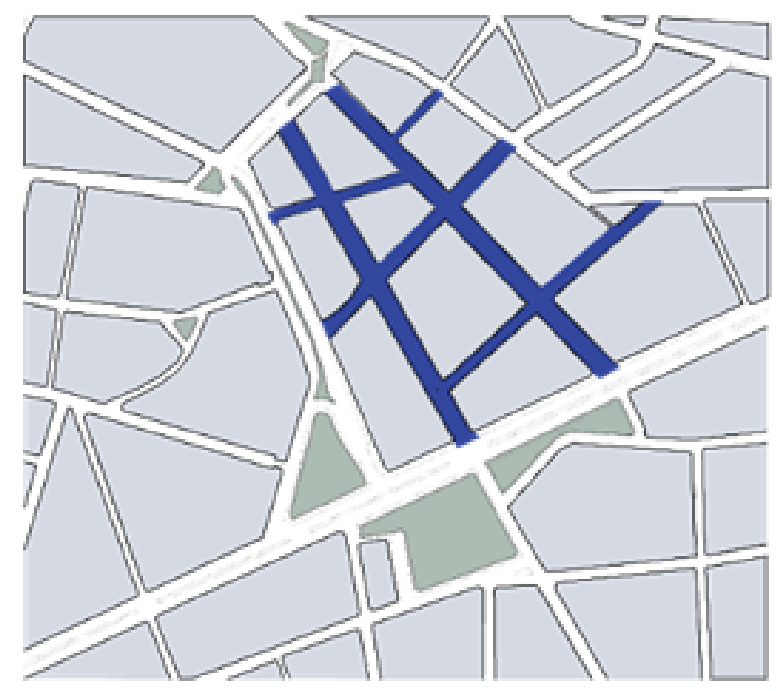

CALCADÁO em 1982

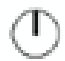
e atualmerto

Figura 02: Extensão do Calçadão em 1975, atualmente e em 1982.

Fonte primária: Mapas - Urbanização de Áreas para pedestres - SEPLAM. Redesenho: Os autores, 2018. 
os locais. Entretanto, todos os nomes que o calçadão em estudo possuiu e ainda possui tem algum nível de ligação com o local.

Inicialmente o local foi chamado de Calçadão da Flórida, em homenagem a Sorveteria Flórida que, na década de 1970, era um dos locais de encontro mais famosos da cidade. Além disso, na época da construção do calçadão, a Sorveteria se situava no Edifício São Luiz, localizado em uma das esquinas do Calçadão.

Entretanto, o local é oficialmente nomeado de Calçadão Jimmy Oliveira (ver fig. 03), uma homenagem ao jovem campinense que era envolvido com política e esporte. Foi suplente de vereador, cargo que o fez visitar Brasília, e ao regressar da capital brasileira, sugerir implantar um local parecido ao que viu no Distrito Federal. Sendo assim, foi ele que deu o pontapé inicial para a ideia de trazer as ruas pedestrianizadas à cidade, originando assim o
Calçadão. Após sua trágica morte, que comoveu toda a cidade na década de 1970, o Calçadão recebeu o seu nome. Uma placa foi posta no local, nomeando-o. Hoje essa placa tem difícil leitura, estando atrás de um dos fiteiros ali presentes.

Todavia, desde a sua criação até os dias de hoje, o calçadão ficou conhecido como Calçadão da Cardoso Vieira, nome original da rua que antecede a sua pedestrianização. Esse é também o nome oficial do trecho não pedestrianizado da via. Paraibano, Cardoso Vieira nasceu em 1848 e foi filho de um senhor de engenho. Elegeu-se deputado geral pelo Partido Liberal em 1878 e lutou, ao lado de Joaquim Nabuco, pelo abolicionismo. É ainda o patrono da Cadeira $\mathrm{N}^{\circ} 10$ da Academia Paraibana de Letras (FERREIRA, 2011). Cardoso Vieira deu nome também a uma rua da capital paraibana, João Pessoa.

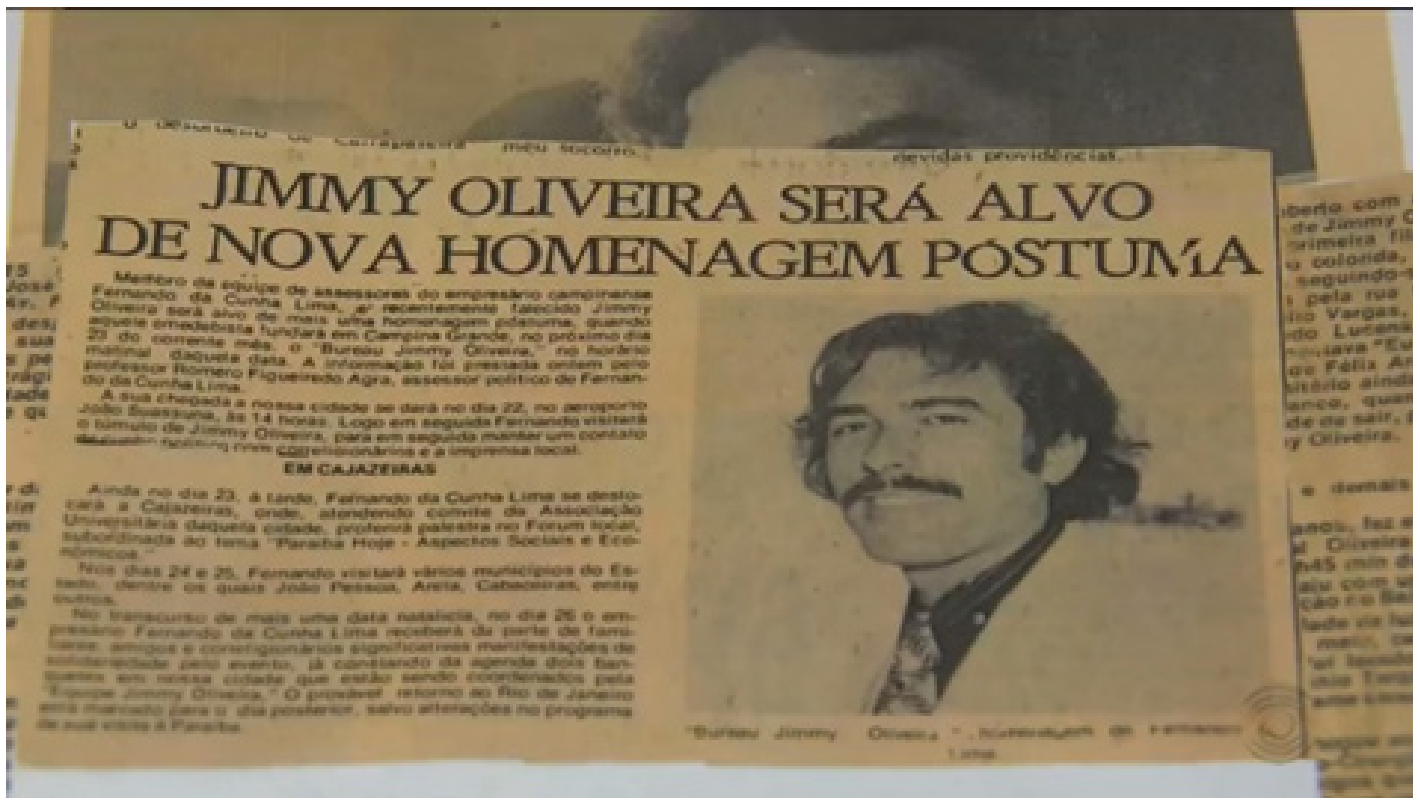

Figura 03: Recorte de jornal acerca de homenagem póstuma a Jimmy Oliveira. Fonte: Jornal da Paraíba (Online). 


\subsection{Memória Coletiva e sensação de PERTENCIMENTO}

A memória coletiva para Nascimento et. al. (2014) pode ser entendida a partir da ritualização de atividades interacionais por um longo período de tempo dos frequentadores do local. "Evocando sempre o passado e projetando perspectivas do futuro, a construção da memória coletiva extrapola a barreira da subjetividade para se tornar uma ferramenta identitária, que demarca experiências vividas em coletividade." (NASCIMENTO et. al, 2014, p. 114).

Por sua vez, a sensação de pertencimento, de acordo com Cavalcante e Elias (2017), surge a partir do momento que a pessoa se percebe como pertencente a um grupo e a um lugar específico, não sendo um estado, mas um processo. Esse processo faz com que o sujeito se projete no espaço e o transforme em um prolongamento de si mesmo, criando um lugar seu. "O processo de apropriação varia em intensidade. O grau mínimo de apropriação se dá pelo olhar, que torna coisas conhecidas, suscitando no observador um sentimento de domínio e familiaridade em relação ao objeto ou lugar." (CAVALCANTE; ELIAS, 2017, p. 63).

Para o levantamento da memória do local e da sensação de pertencimento foi definido como principal instrumento de coleta a aplicação de entrevistas semiestruturadas com fechamento amostral por saturação teórica. Essa opção metodológica ocorreu em função do universo ser de difícil mensuração: atores, agentes e usuários de um modo geral, permanentes e transitórios. Além disso, a partir das observações sistemáticas realizadas foi possível identificar que o universo é bastante homogêneo: idosos aposentados. Não houve escolha de um único público-alvo anterior à aplicação das entrevistas, entretanto, como o universo trabaIhado possui essa característica homogênea, as entrevistas foram realizadas majoritariamente com o mesmo perfil: homens aposentados com mais de 50 anos.

Pelo método de aplicação de entrevistas semiestruturadas com fechamento amostral por saturação teórica, a realização das entrevistas se encerra quando os dados passam a apresentar, de acordo com o pesquisador, uma certa redundância ou repetição. Nesse caso, considera-se que as informações repassadas por novos entrevistados acrescentariam pouco aos resultados já obtidos, não contribuindo mais de forma significativa, para o aprofundamento das categorias analíticas definidas previamente no roteiro da entrevista (STRAUSS; CORBIN, 2008).

As perguntas presentes na entrevista possuíam respostas abertas, o usual para entrevistas semiestruturadas, para que assim a fala dos entrevistados pudesse revelar diferentes aspectos acerca da memória coletiva do local. As questões da entrevista buscavam explorar o entendimento sobre os elementos, os atributos e os significados atrelados ao local de estudo.

A primeira delas, relacionada às transformações que ocorreram durante os anos no Calçadão, recebeu respostas bastante variadas. $\mathrm{H} 017^{7}, 62$ anos, respondeu da seguinte forma:

Ah, com certeza, o Calçadão mudou muito né? Teve um tempo que tentou se criar aqui o que se tem em algumas metrópoles. Fortaleza por exemplo, a parte inteira do centro que não tem trânsito, uma espécie do que são calçadões no plural. Aqui se tentou fazer também. Fez na Maciel Pinheiro que não passava carro, tinha banquinho para as pessoas, tentando talvez esvaziar esse calçadão da Cardoso Vieira, só que não vingou. Aí voltou pra cá e permanece até hoje, então aqui já é um patrimônio sim. E aqui tem umas coisas interessantes. Como por exemplo, a divisão das duas torcidas que naturalmente elas ficaram divididas. Esse lugar que estou aqui (extremidade da rua Marquês do Herval), aliás eu estou errado né? Que eu sou raposeiro. Desse

7 Para a proteção da identidade dos entrevistados, os seus respectivos nomes foram substituídos por codinomes (H01 para entrevistadas do sexo masculino e M01 para entrevistadas do sexo feminino). Contudo, como será visto mais a frente, os entrevistados considerados "atores" do calçadão não pa considerados figuras singulares do local, onde suas identidades possuem valor para a análise. Todos os entrevistados permitiram o uso de suas falas e imagens a partir da assinatura de termos de consentimento presentes no processo do projeto com Certificado de Apresentação para Apreciação Ética Nº 00271218.9.0000.5182 para o Comitê de Ética de Pesquisa do Ministério da Saúde. 
lado de cá ficam os trezeanos e ali os raposeiros. E eles ficam brincando, as vezes até xingando né? E aquela motivação toda dos dois times ocorre no calçadão que é o grande point das arenas e tal. Com essa divisória né? Trezeanos pra cá, raposeiros pra lá. (Entrevista no Calçadão, no dia" 10/11/2018)

H11, 69 anos, volta a sua resposta para a sociabilidade dos frequentadores do Calçadão:

Eu quase não percebi porque isso aqui é uma variedade muito grande, é um complexo. É gente de toda espécie, todo jeito. Gente que tem patrimônio, gente que não tem. Gente de toda qualidade. E quando a gente observa essa coisa é meio complicado. É uma questão que tem que ser estudada e eu me dedico exclusivamente ao fuxico, as brincadeiras. Agora aqui sempre tem essa revolução, tem de empresário a batedor de carteira, pistoleiro, viado, sapatão, corno, mal casado, toda qualidade de gente visita isso aqui. Aqui é um todo, representa a cidade tranquilamente. (Entrevista no Calçadão, no dia 10/11/2018)

H03, 68 anos, reflete sobre as mudanças físicas que aconteceram no Calçadão, atentando também para a falta de atenção pelo poder público:

Houve três reformas, e olhe que o Calçadão é antigo, tem quarenta anos. E olhe que os órgãos públicos devem dar uma olhadinha para cá. Imagina isso aqui com uma cobertura, ou aumentar mais a vegetação. Precisa de mais atenção, tanto é que por conta de falta de atenção foi cortada uma árvore que tinha aqui. (Entrevista no Calçadão, no dia 10/11/2018)

As perguntas relacionadas aos significados do lugar e à memória coletiva tiveram respostas sempre voltadas para a coletividade local. H12, 58 anos, relembra memórias futebolísticas: "A comemo-

8 Treze Futebol Clube e Campinense Futebol Clube são os dois times de futebol mais importantes da cidade, possuindo rivalidade histórica entre os seus torcedores. ração das vitórias do Treze e do Campinense, eram aqui. A gente vinha lá do estádio municipal, do José Pinheiro, a pé para cá".

H04, 58 anos, também possui memórias acerca do futebol: "Quando existia o futebol em Campina Grande. Tudo se concentrava aqui no Calçadão, quando o Treze ganhava ou o Campinense. Tudo vinha parar aqui. E acontecimentos políticos também, né? Aqui já passaram grandes políticos a nível nacional, como agora há pouco o presidente eleito esteve aqui. Isso não é pra todo mundo não, ter o presidente comendo queijo aqui".

H06, 57 anos, relembra um caso inusitado que aconteceu no calçadão há alguns anos:

Os boladores de coco que eram duas mulheres, aí tão ali na maior embolada do mundo. Aí chega aqui um conhecido vulgarmente conhecido como o "Bode Rei" pega uma bomba de São João, aquelas bombas falsas deste tamanho (faz gesto com as mãos) e joga no meio da multidão. Não prestou não viu? O pau comeu, policial, todo mundo correu. Quem tava no Calçadão correu achando que era uma bomba de verdade. Essa cena foi inesquecível para mim. (Entrevista no Calçadão, no dia 10/11/2018)

A última pergunta da entrevista semiestruturada é relacionada aos pontos negativos e positivos do calçadão. Acerca dos pontos negativos, os mais citados foram: a questão da segurança, do comércio informal e a necessidade de uma reforma. Acerca do último ponto, H01, 62 anos, discorre: "O Calçadão passou por diversas reformas físicas, vocês já podem perceber que tá aqui querendo uma nova. Poderia ficar um ambiente mais aprazível. Física mesmo, o piso aqui tá bem sofrido..." .

Os entrevistadores perguntam: Além do piso, poderia ter algo a mais?

Ele conclui:

Não, porque eu acho que assim, as atrações, as pessoas mesmo se encarregam de trazer pro Calçadão. Até mo- 
vimentações políticas as vezes é ali na praça, mas se diz, não na praça as pessoas olham, mas não chegam. No Calçadão tão começando também a criar um ambiente que é aquele ambiente da realização das manifestações políticas. (...) eu acho que o calçadão tá sendo descoberto pra isso também. Então aqui é lugar de artistas populares, né? De boladores de coco. De grupos de capoeira, de grupos religiosos. Agora para o porte de Campina Grande, poderia estender isso aqui né? Que é muito pequeno. Quem sabe você não poderia interditar uma dessas ruas, formando uma espécie de $L$ aqui com a Venâncio Neiva (Rua perpendicular ao Calçadão). Aqui é muito pequeno para a quantidade de eventos. (Entrevista no Calçadão, no dia 10/11/2018)

H08, 58 anos, discorre sobre as amizades criadas e cultivadas no local:

As amizades que a gente constrói, os amigos que volta a ver aqui, muita coisa que de uma forma ou de outra, eu vi amigo de 30, 40 anos que reencontrei aqui. Amigos de São Paulo que vi aqui no calçadão que é o point de Campina. (Entrevista no Calçadão, no dia 10/11/2018)

H06, 57 anos, também fala acerca das amizades no local:

Positivo pra mim é que isso aqui é uma família. A gente se encontra aqui. E é uma família, tudo aqui é possível. Aqui tira o stress, aqui é um consultório, principalmente pra doido. Consultório pra doido, consultório pra corno. Aqui não é moleza não. Aqui é uma terapia, um relaxamento total, não tem stress. Creio que $80 \%$ das pessoas daqui vem com um problema sério, aí já passa um doido gritando, o ponto positivo daqui é isso, é a alegria, o riso, é exercitar os músculos, coisas que raramente se vê, né isso? (Entrevista no Calçadão, no dia 10/11/2018)

A partir da leitura das respostas dos entrevistados fica claro o apego que os mesmos sentem em relação ao local. A grande maioria dos entrevistados relataram a necessidade de uma nova reforma para o Calçadão, como também, citam questões como falta de acessibilidade e segurança. Mostrando que, mesmo com esses problemas, o Calçadão ainda é o local de preferência deles. Questões de sociabilidade também se mostraram muito fortes. O Calçadão é o lugar onde todos se conhecem, muitos se conhecem há décadas, possuindo laços fortes tanto entre os usuários do local, quanto entre os usuários e o próprio Calçadão. A história e a memória local se misturam, assim, com a história e a memória dos usuários, sendo impossível separá-los.

\subsection{Atores do Calçadão}

A história do Calçadão se confunde com a história de indivíduos que estão presentes no local, muitas vezes, desde a sua construção. São atores, espectadores e difusores dos acontecimentos que envolvem o Calçadão, tornando-se, assim, parte essencial da paisagem do Calçadão, como também, importantes fontes para a pesquisa da memória do lugar. A seguir alguns desses atores serão apresentados.

\subsubsection{Seu Lourival}

Lourival Lopes Barbosa, 63 anos, comerciante proprietário de uma banca de revistas, conhece o calçadão antes mesmo dele ter sido construído. Durante a nossa entrevista, brinca: "Estou aqui há três decênios e meio. Vocês sabem o que é um decênio? Se caísse no ENEM já era uma questão perdida, né?" Ele ainda lembra que no mês anterior a entrevista (Outubro/2018), o Calçadão havia completado 43 anos. De modo que sua inauguração aconteceu no ano de 1975.

Sobre esse período, o mesmo lembra:

Olhe, esse Calçadão já passou por três reformas. E na minha opinião o original, porque sempre o original permanece na memória, né? É como a primeira namorada, vira um marco na memória e na minha opinião a primeira reforma foi a melhor. (...) Quando eu cheguei aqui a (Sorveteria) Flórida era o point 


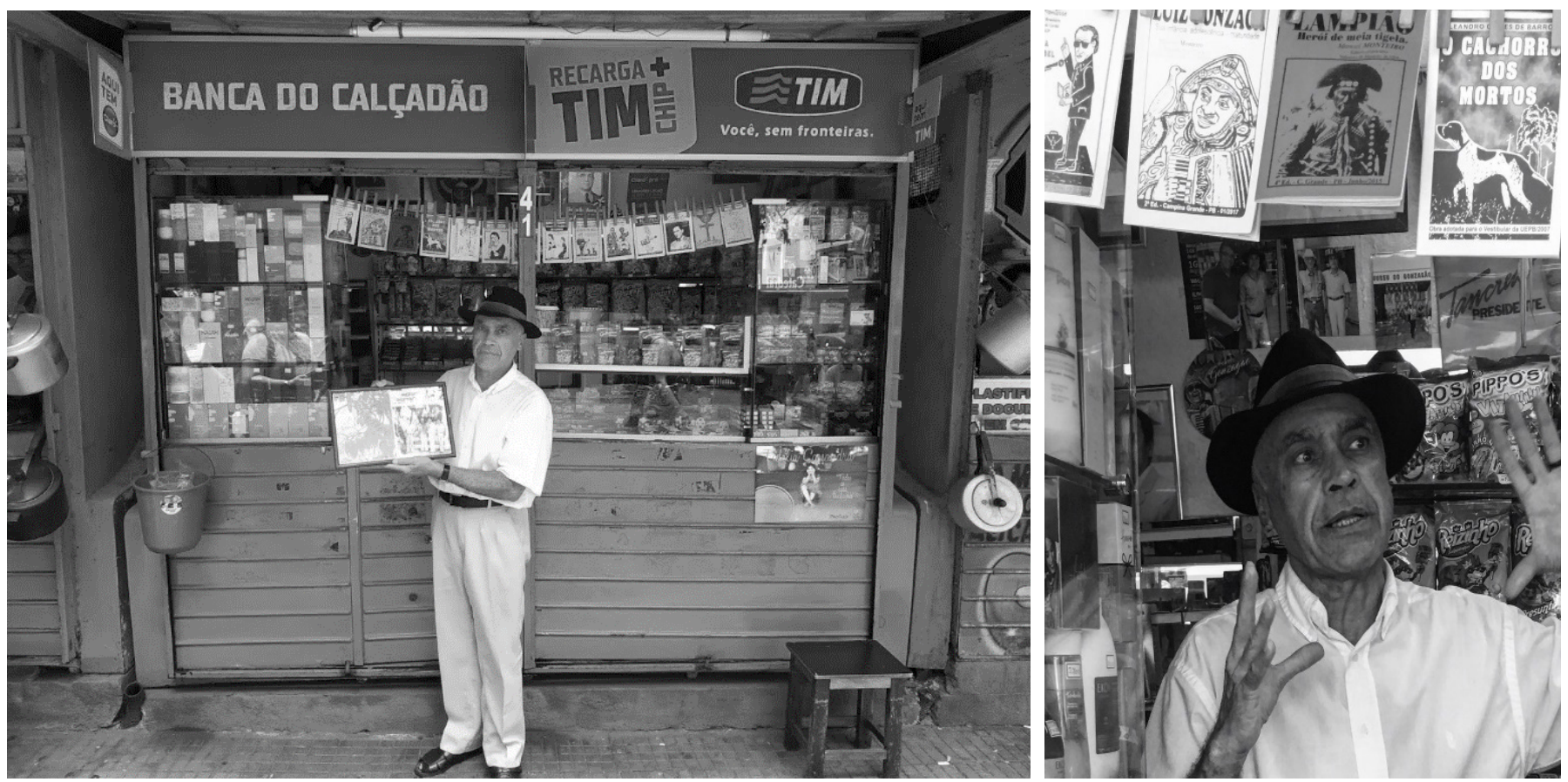

Fig. 04: Seu Lourival em frente a sua banca. Fonte: Arquivo pessoal, 2018

de encontro daqui de Campina, mas ela já tinha saído daqui. A Rádio Borborema também. Aqui só tinha o cafezinho São Braz. (Entrevista no Calçadão, no dia 10/11/2018)

Além do aspecto comercial da área, que para ele é muito bom devido ao fluxo intenso de pessoas, Seu Lourival lembra do aspecto que mais lhe marcou na história do calçadão: o futebol. "O que mais me marcou aqui no Calçadão nesses 45 anos foi o futebol. O Treze x Campinense, porque era realmente uma festa. Começava já no sábado, a venda de ingressos e no domingo continuava".

\subsubsection{Wellington dos Laticínios}

Outra figura que está presente no calçadão há trinta e quatro anos é Wellington Barbosa - mais conhecido como Wellington dos Laticínios (ver fig. 05). Para o comerciante, o "Calçadão é o centro de irradiação do universo. Tudo começa aqui e termina aqui, no Calçadão".

Para ele, as maiores transformações que aconteceram no calçadão foram de aspecto cultural, sendo o que mais mudou foram:

Os costumes do povo. Quando eu comecei há trinta e quatro anos aqui era um ponto muito bom, onde se encontravam os intelectuais, escritores, poetas, advogados, juízes, comerciantes. Era a massa cultural da cidade antigamente. Mas, com o passar do tempo, e devido à falta de estacionamento, poluição sonora, isso mudou. Hoje a segurança é outro fator muito primordial nisso aí. Antigamente, o pessoal ficava aqui até 11 horas - meia noite, batendo papo na subida desse supermercado que chamava o Senadinho, devido aos batentes parecia um senado mesmo, todo 


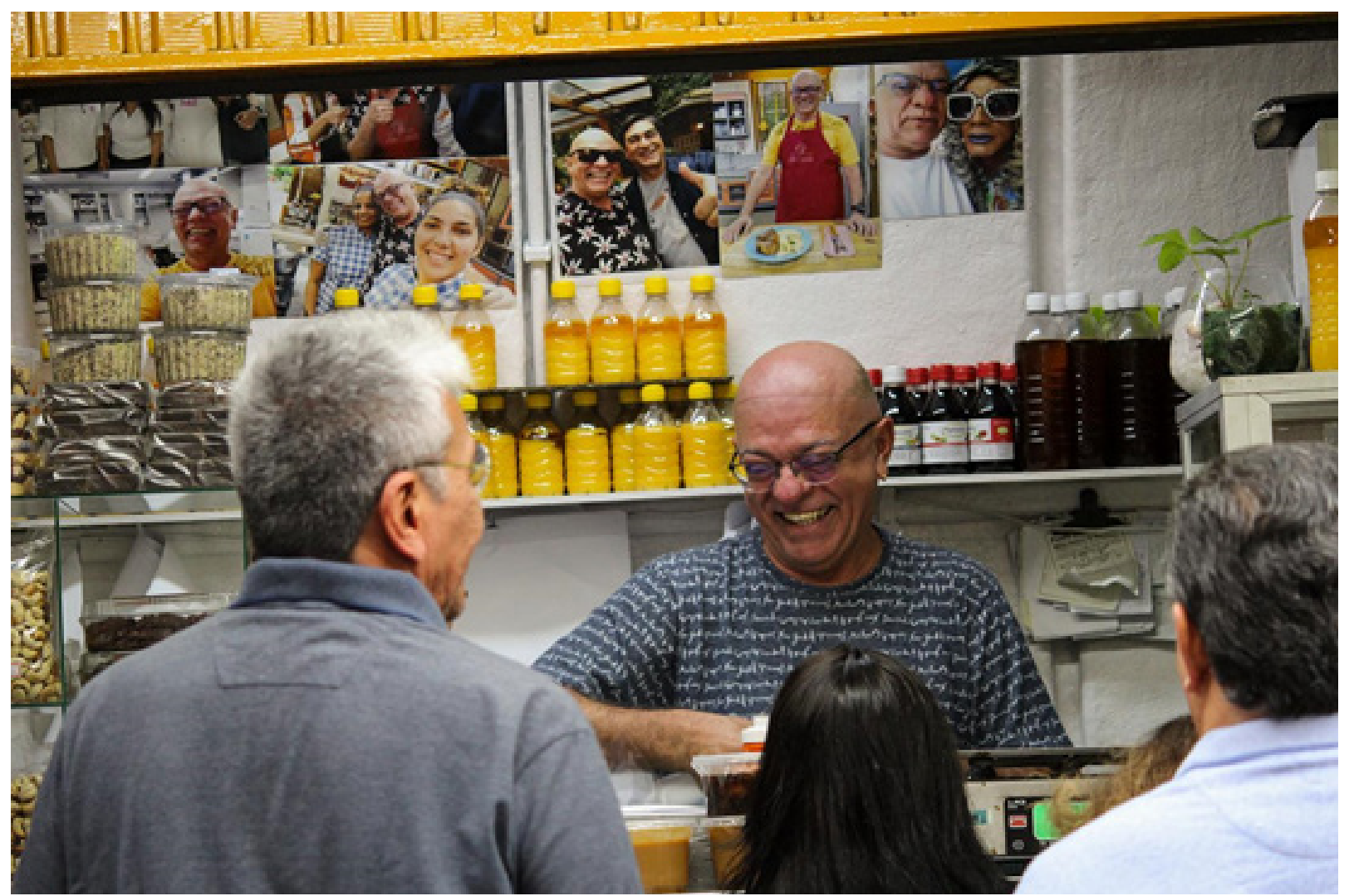

Figura 05: Wellington Latícinios.

Fonte: Repórter Junino (2019).

mundo ficava ali batendo papo, hoje em dia ninguém mais pode ficar. Tem um tal de churrasquinho que botam de um lado e de outro (referindo-se aos extremos do calçadão) e só puxa bêbado, marginais, todo tipo de gente que não presta. Meu horário de trabalho, a minha jornada, era até 8-9 horas da noite, hoje em dia quando dá 19h, eu tô indo embora, eu não me sinto seguro. Tudo isso foi afastando o pessoal daqui, então foi uma mudança de costume, cultural por sinal, né? Hoje em dia ninguém vem mais. (Entrevista no Calçadão, no dia 10/11/2018)

\subsubsection{Biliu de Campina}

Severino Xavier de Sousa, 69 anos, mais conhecido como Biliu de Campina, é um dos atores mais conhecidos do calçadão. Além de ser um assíduo usuário do local, Biliu é um músico que se utiliza do espaço para fazer as suas apresentações.

Para o músico, o Calçadão "significa tudo. É uma parte da vida da gente. Eu acho que é um conselho médico mesmo, na prática. Se eu não vir aqui eu adoeço. Aqui faz parte da vida da gente. Serve 


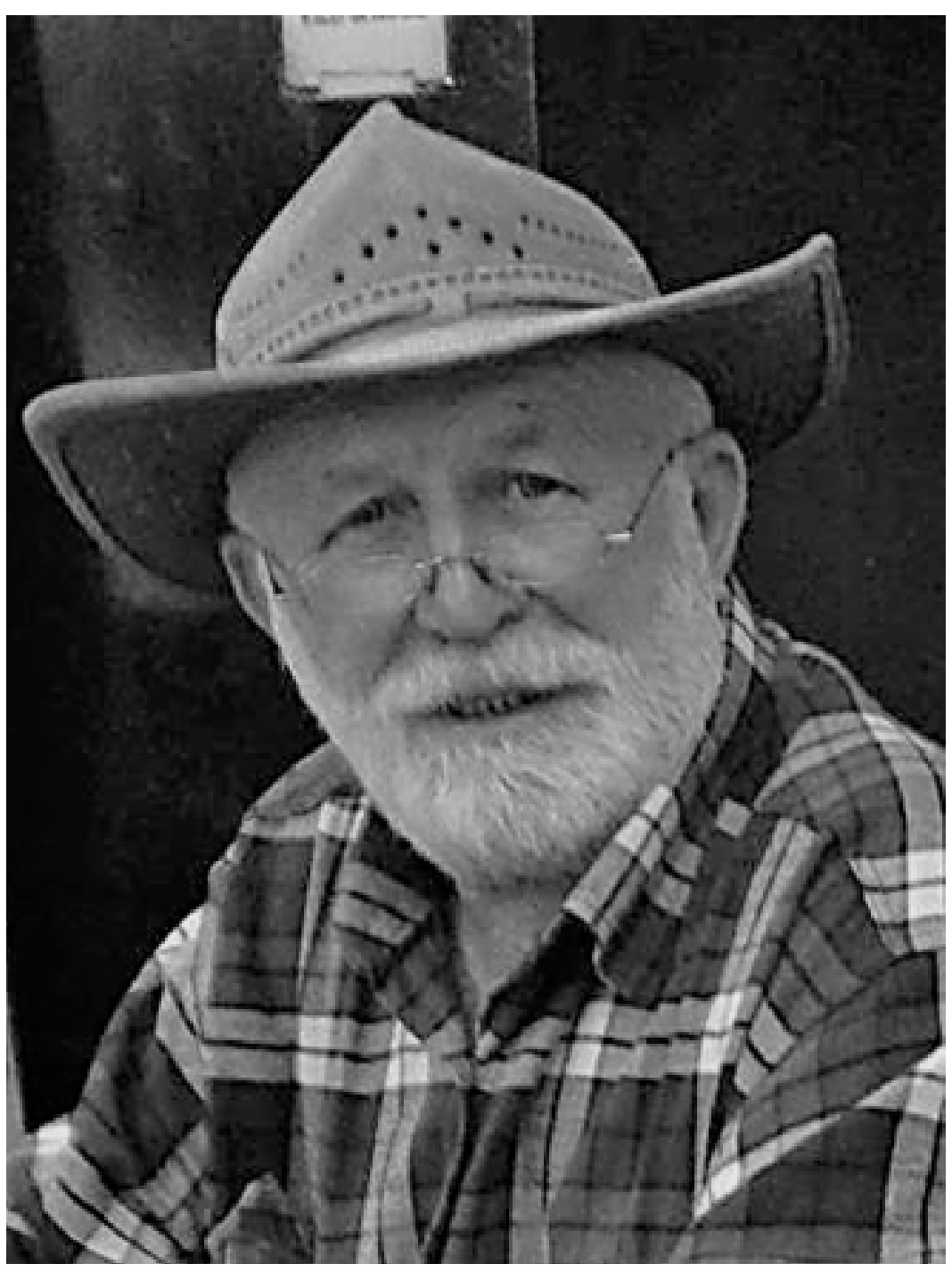

Figura 06: Biliu de Campina.

Fonte: Museu do Esporte de Campina Grande. pra tudo, pra alegria, pra raiva, o que você pensar e imaginar, aqui manifesta tudo".

Quando perguntado sobre algum acontecimento que saltasse a memória acerca do calçadão, Biliu lembra de um personagem da história do calçadão, o "doido" Caraboreto:

Aqui tinha um doido que me saudou a memória agora, chamado Caraboreto. Uma vez, um cara pra se informar perguntou: aonde fica a Cavesa (concessionária da Wolksvagem) aqui? O cara tava ali no fiteiro de Welligton. Welligton a pessoa compra $1 \mathrm{~kg}$ de quejo e só vem $900 \mathrm{~g}$ e o problema não é de balança não, é que ele é ladrão mesmo (diz rindo). Welligton do queijo ali e eu tô fazendo essa propaganda pra ele. Aí sabe o doido acolá? Chamava Caraboreto. Aí o doido tava ali e o cara disse: meu amigo, eu tô com um wolksvagem e deu um problema, onde é a Cavesa? Ai Caraboreto olhou e disse: é la embaixo, tu pega essa rua aqui do capitólio e do babilônia, desceu direto, a Cavesa é lá embaixo. Aí o cabra olhou e disse: Seu nome não é Caboreto, né? E você não é doido? "Sou doido mas não sou burro não, burro é você seu imbecil." Pra ser doido em Campina precisa ter muito juízo, ele dizia. Era uma figura folclórica daqui. (Entrevista no Calçadão, no dia 10/11/2018)

Para terminar sua fala, começa a cantarolar: "Tudo aqui é bom. Aqui tem pinico pra potó, muleta pra saci, espanador de rabo de cutia, chove no molhado, tem esse aqui (aponta para o amigo) que foi educado por um papagaio de cabaré, muito educado fino. Aqui tem preto, viado, cigano, índio, sapatão, pistoleiro, empresário, corno, mal casado. Tudo que você pensar e conceber socialmente você tem representado aqui".

\subsection{Uso ATUAL}

A partir das observações feitas e das entrevistas semiestruturadas foi gerado um mapa de usos do local. Apesar de ser um espaço relativamente pequeno, o Calçadão agrega uma série 
diversa de frequentadores e de usos, como pode ser visto a seguir na figura 07:

Pode-se perceber assim a vocação do local para usos de comércio e de lazer. O grupo de usuários caracterizado como idosos se apropria do calçadão principalmente, mas não exclusivamente, para a questão da sociabilidade. Essa apropriação se faz por meio da divisão dos idosos a partir das torcidas dos dois maiores times de futebol da cidade, mais conhecidos como Treze (galo) e Campinense (raposa). Tal grupo de idosos pode ainda ser dividido em menores grupos, como os de ex-esportistas, empresários e advogados.

Os demais grupos de usuários se utilizam do Calçadão para o uso comercial e prestação de serviços. Como pode ser percebido no espaço, o uso comercial é o que mais se destaca. O comércio

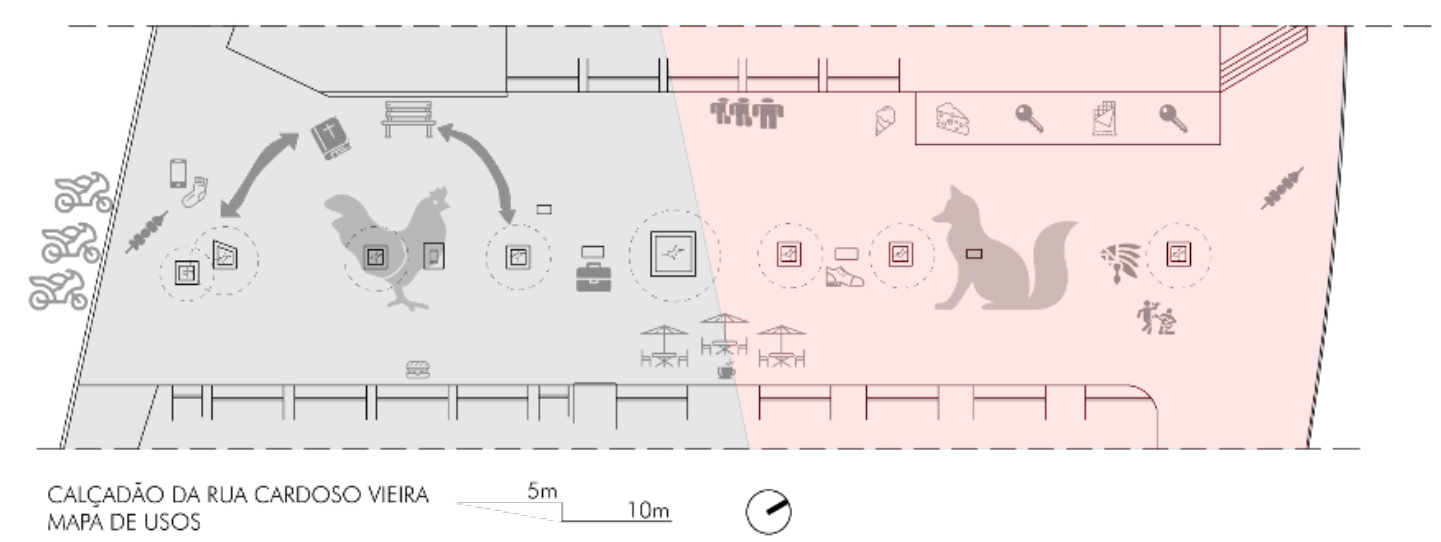

\section{LEGENDA}

4 Área dos torcedores do Treze Futebol Clube

Wr Área dos torcedores do Campinense Futebol Clube

ॠ्2 Mototaxistas

Churrasquinho (noturno)

פg. Comércio informal (fora do horário comercial)

Fluxo de idosos em busca de sombra

Q Pregações religiosas

\# Banco improvisado pelos idosos

- Concentração de ex-esportistas, empresários e advogados

嘪 Consumo (Henrique Lanches)

10 Consumo (Café São Braz)

20nsumo (Banca de Sorvete)

Consumo (Banca da Oi)

Figura 07: Mapa de usos do Calçadão.

Fonte: 0 autor (2018).
Tำ Mesas para consumo (Café Sāo Braz)

ED Área dos engraxates

wîi Fila de pessoas (Loterica)

Consumo (Banca Welligton dos Latícinios)

a Consumo (chaveiros)

Consumo (Banca do seu Lourival)

Área de exposição de produtos indígenas

植 Área de apresentaçōes e eventos maiores 
informal oferece uma variada gama de objetos (meias, celulares, relógios etc). Por sua vez, o comércio formal também é bastante variado. Pode-se comprar no local: laticínios, chaves, cordel, consumir comida e bebida etc. A prestação de serviços é realizada por meio da Lotérica instalada no pavimento do subsolo do Edifício Lucas (que pode ser visto no plano de fundo da primeira imagem da Figura 08, com a antiga "Farmácia do Calçadão"), onde é possível pagar boletos e realizar transações bancárias.

Outras formas de apropriação podem ser vistas no calçadão, de forma ocasional. É o caso das pregações religiosas, das apresentações de música ao vivo e da exposição de artigos de grupos indígenas do Estado.
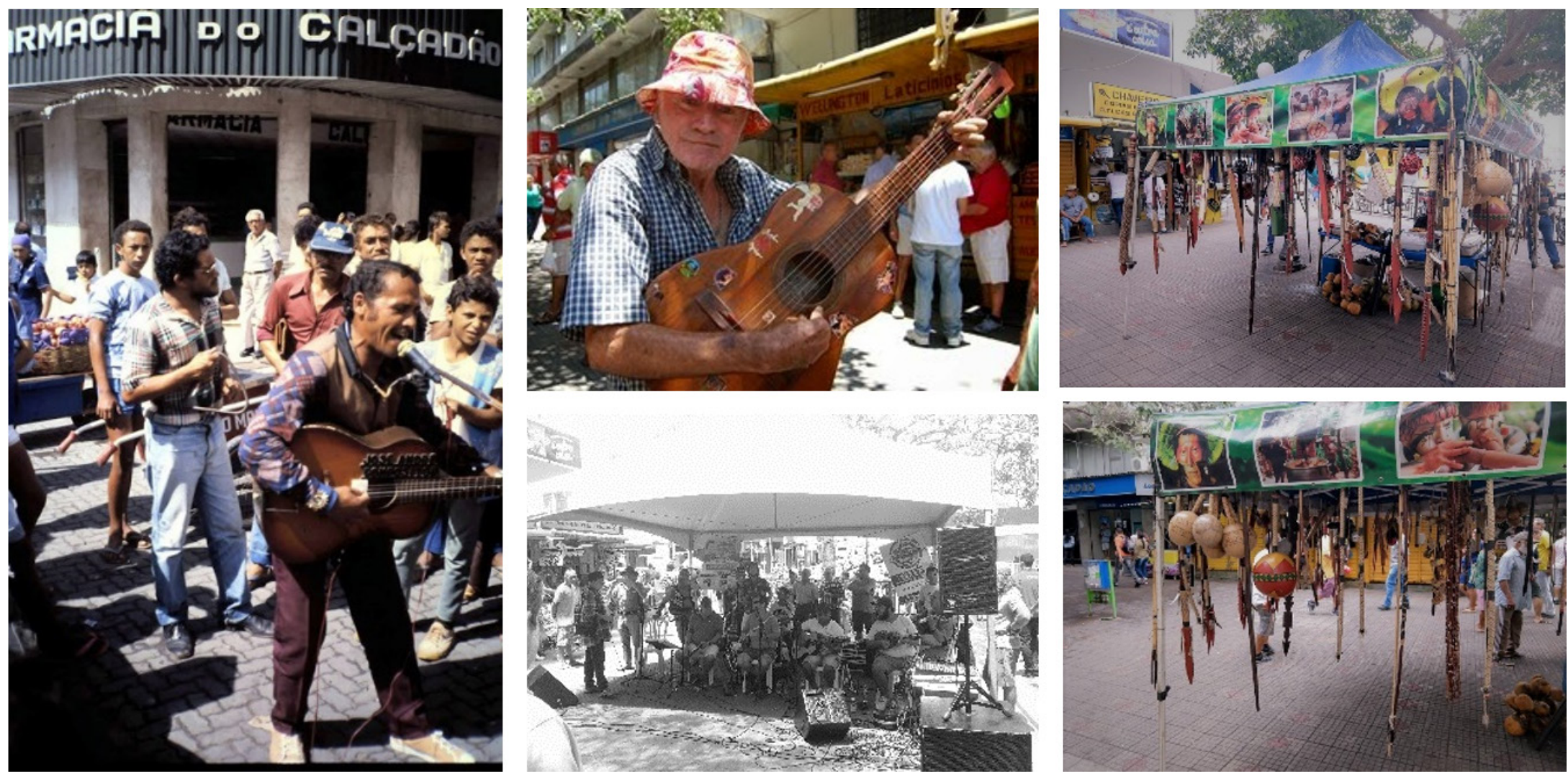

Figura 08: Apropriações do Calçadão: (Da esquerda pra direita)

1. Cantores na década de 1990

2. Biliu de Campina em 2007;

3. Grupo de Samba se apresentando em 2018

4. Tenda de produtos de grupo indígena do Estado.

Fontes: 1/2 BlogCGRetalhos 3/4 Arquivo Pessoal (2018). 


\section{Conclusão}

A teoria da conservação da paisagem, como pode ser visto, é algo recente nas políticas de preservação patrimonial. Usualmente, quando se refere à conservação das paisagens, prioriza-se a conservação daquelas excepcionais, de valor universal. Durante todo o presente artigo, procurou-se elencar os elementos intangíveis que fariam das paisagens não tão notáveis, as verdadeiramente ditas ordinárias, também dignas de serem conservadas. A partir dos resultados apresentados, fica claro que no objeto empírico do presente trabalho, o Calçadão da Cardoso Vieira, o valor dos elementos ali agregados não possuí um caráter universal, onde qualquer pessoa no globo pode se relacionar facilmente a tais elementos.

Como uma paisagem ordinária, do dia a dia, uma paisagem não tão notável, os elementos intangíveis ganham importância em uma escala micro, entre os usuários do local e a memória ali construída. Devido a todas as medidas higienistas propostas pela Prefeitura Municipal a partir da década de 1930, a apropriação não só do Calçadão, mas de todo o Centro Histórico de Campina Grande, possui um cunho elitista, com ideal modernizador. Destaca-se também o perfil homogêneo de usuários, onde o grupo de homens idosos se caracteriza como aquele que permanece por mais tempo no local. Entretanto, pode ser percebido, a partir da aplicação das entrevistas semiestruturadas e da observação da dimensão humana, que os grupos ali presentes fazem parte da história do local e são difusores da memória da cidade, possuindo níveis altos de pertencimento e identidade para com o local.

Muitos dos atores entrevistados estão ali presentes há mais de quarenta anos, onde as suas histórias se confundem com a história do próprio Calçadão. Dessa forma, a paisagem do Calçadão não existe sem eles, assim como, as personas que eles representam para o imaginário popular não existem sem essa paisagem. O que mostra que não são apenas as paisagens que possuem atributos excepcionais que merecem ter todos os seus elementos preservados. As paisagens do dia a dia, não tão notáveis para tantas pessoas, são especiais para a população local. Podem não extrapolar fronteiras regionais ou nacionais, mas a sua significância local é inquestionável.

Assim, é necessário que os elementos intangíveis do local passem a ser trabalhados por políticas públicas municipais, na tentativa de preservar a história local para as gerações presente e futuras. Os atores do Calçadão não estarão ali para sempre, mas as suas histórias podem e devem ser difundidas como parte importante da própria história da cidade e para a criação de laços futuros de novos atores que um dia irão se encontrar ali.

\section{Bibliographic References}

CABRAL, Renata Campello. A noção de "ambiente" em Gustavo Giovannoni e as leis de tutela do patrimônio cultural na Itália. Tese (Doutorado em Arquitetura e Urbanismo) - Instituto de Arquitetura e Urbanismo da Universidade de São Paulo, São Paulo, 2013.

CARVALHO, Maria Jackeline. Para além da pedra e cal: discursos e imagens de Campina Grande (1970 a 2001). Campina Grande: EDUEPB, 2017

CAUQUELIN, Anne. A Invenção da paisagem. São Paulo: Martins, 2007

CARSALADE, Flavio de Lemos. Cultura, identidade, conservação: espaço público, sociabilidades, patrimônio cultural. In: FERNANDES, Ana Cristina; LARCEDA, Norma; PONTUAL, Virgína (Org). Desenvolvimento, planejamento e governança: o debate contemporâneo. $1^{\text {a }}$ ed. Rio de Janeiro. Letra Capital: ANPUR, 2015.

CAVANCALTE, Sylvia; ELIAS, Terezinha Façanha. Apropriação. In: Temas básicos em psicologia ambiental. CAVALCANTE, Sylvia; ELALI, Gleice A. (orgs.) Petrópolis, RJ: Vozes, 2017.

CHAWLA, Louise. Childhood Place Attachments. In: LOW, Setha.; ALTMAN, Irwin. (orgs.). Place Attachment: Human Behavior and Environment - Advances in Theory and Research. Boston, MA: Springer, 1992.

DANTAS, Hugo Stefano Monteiro. O Calçadão da Cardoso Vieira: Paisagem (não tão) notável do centro histórico de Campina Grande (PB). Monografia (Graduação em Arquitetura e Urbanismo) - Universidade Federal de Campina Grande. Campina Grande, 2018.

DI MAIO, Sara; BERENGO, Cecília. Nós somos a paisagem: como interpretar a Convenção Europeia da Paisagem. Guimarães. MAPa2012, 2011. Disponivel em: https://www ufpe br/documents/39726/0/N\%C3\%93S+SOMOS+A+PAISAGEM.pdf/44364e4a-11cf-48b3-a5fc-3df854b0f97f. ments/39726/0/N\%C3\%93

DITTRICH, Maria Glória; REVORÊDO, José Cláudio dos Santos; OLIVEIRA, Micheline Ramos: RAMOS, Flávio; GOLEMBIEWSKI, Carlos. O calçadão de Curitiba: sua história como espaço público social da cidade. In: Revista Brasileira de Tecnologias Sociais, v.2, n.2, 2015. doi: https:// doi.org/10.14210/rbts.v2n2.p173-184.

FERREIRA, Rau. Memória: Cardoso Vieira. Retalhos Históricos de Campina Grande, 2011 Disponível em: http://cgretalhos.blogspot.com/2011/02/memoria-cardoso-vieira.html\#.W5GVJ-hKhPZ. Acesso em: 06 set. 2018. 
GEHL INSTITUTE. Public life diversity toolkit - Volume 2. March, 2016. Disponível em: https:// issuu.com/gehlinstitute/docs/20160128_toolkit_2.0. Acesso em: 27 ago. 2018.

NASCIMENTO, Roberta N. Araújo; ANDRADE, Antônio Carlos de S.S.; OLIVEIRA, Carla Cordeiro de. Reminiscências históricas: a oralidade como ferramenta de construção da memória dos espaços urbanos de Campina Grande. In: Temática. ano X, n.11, 2014.

NÓR, Soraya. O lugar como imaterialidade da paisagem cultural. In: Paisagem e Ambiente: Ensaios - N. 32, São Paulo, p. 119-128, 2013.

QUEIROZ, Marcus Vinícius Dantas de. Quem te vê não te conhece mais: arquitetura e cidade de Campina Grande em transformação (1930-1950). Dissertação (Mestrado - Programa de Pós-Graduação em Arquitetura e Urbanismo e Area de Concentração Teoria e História da Pos-Graduaça Arquitetura e Urbanismo Paulo, 2008

STRAUSS, Anselm.: CORBIN, Juliet. Pesquisa qualitativa: técnicas e procedimentos para o desenvolvimento de teoria fundamentada. $2^{\mathrm{a} e d}$. Porto Alegre: Artmed, 2008.

UNESCO. Operational Guidelines for the Implementation of World Heritage Convention. 1999. Disponível em: https://whc.unesco.org/archive/opguide99.pdf. Acesso em: 03 abr. 2018.

UNESCO Operational Guidelines for the Implementation of World Heritage Convention. 2017. Disponível em: https://whc.unesco.org/en/guidelines/. Acesso em: 18 abr. 2018.

UNESCO. Convenção para a Salvaguarda do Patrimônio Cultural Imaterial. 2006. Disponíve em: https://unesdoc.unesco.org/ark:/48223/pf0000132540por. Acesso em: 18 maio 2019.

VERAS, Lucia Maria de Siqueira. Paisagem-postal: A imagem e a palavra na compreensão de um Recife urbano. Tese (Doutorado em Desenvolvimento Urbano) - Universidade Federal de Pernambuco, Recife, 2014

ZIAYEE, Maryam. Urban cultural landscape foundations: Materials, immaterials and links. In: 5th International cultural landscape conference, Urban Cultural Landscape; Past, Present Future, Tehran, Iran, 2014

ZIAYEE, Maryam. Assessment of urban identity through a matrix of cultural landscapes. In: Cities. Volume 74, p. 21-31, 2018. doi: https://doi.org/10.1016/j.cities.2017.10.021.
Hugo Stefano Monteiro Dantas

Universidade Federal de Pernambuco (UFPE), Programa de

Pós-Graduação em Desenvolvimento Urbano (MDU).

Avenida da Arquitetura, s/n, Universidade Federal de Pernambuco,

Cidade Universitária, CEP 50740-550, Recife-PE-Brasil

https://orcid.org/0000-0002-8714-7894.

hugostmd@gmail.com

Kainara Lira dos Anjos

Universidade Federal de Campina Grande (UFCG),

Curso de Arquitetura e Urbanismo.

Rua Aprígio Veloso, 882 - Universitário, CEP 58428-830,

Campina Grande - PB.

https://orcid.org/0000-0001-9327-5334

kainaraanjos@gmail.com

Notas do Editor:

Data de submissão: 16/10/2019

Data de Aceite: 18/03/2020

Revisor: RMO 